\title{
Operationeel risicomanagement: meer dan alleen compliance
}

\section{Willem Peter de Ridder}

SAMENVATTING Operationeel risicomanagement staat hoog op de agenda van ondernemingen, wetgevers en toezichthouders, meestal vanuit een compliance en risicobeperkend perspectief. Uit het hier beschreven (actie)onderzoek bij een grote Nederlandse verzekeraar komt naar voren dat risicomanagement ook andere toegevoegde waarde kan hebben voor de onderneming: verbetering van efficiency en kwaliteit en een beter imago bij kredietbeoordelaars, aandeelhouders en klanten. Goed risicomanagement leidt niet tot de totale eliminatie van risico of een auditexplosie, maar tot het bewust nemen van risico in verhouding tot de ondernemingsdoelstellingen.

1

\section{Inleiding}

Alle ondernemingen lopen operationele risico's, varierend van stormschade aan een gebouw, systeemstoringen en het vertrek van belangrijke medewerkers tot boekhoudfouten, interne/externe fraude en misleiding van aandeelhouders. Sinds beruchte schandalen bij ondernemingen als Barings, Enron, Worldcom, Parmalat, Shell en Ahold staat operationeel risicomanagement hoog op de agenda van ondernemingen, wetgevers en toezichthouders.

Operationeel risico is het risico van verlies als gevolg van inadequate of falende interne processen, mensen en systemen of als gevolg van externe gebeurtenissen.

Dr. W.P. de Ridder is operationeel risicomanager bij AEGON. Hij studeerde bedrijfseconomie aan de Erasmus Universiteit Rotterdam en promoveerde oktober 2006 aan de Universiteit van Tilburg op een onderzoek naar de introductie van operationeel risicomanagement. Dit artikel is gebaseerd op zijn dissertatie.
Terwijl financieel risicomanagement, vaak uitgesplitst naar markt- en kredietrisico, al veel langer bestaat en verder is ontwikkeld, is de aandacht voor operationeel risicomanagement relatief nieuw en zijn de methoden hiervoor nog niet uitgekristalliseerd (Leenaars, 2003). Markt- en kredietrisico beperken zich doorgaans tot specifieke activiteiten en afdelingen, laten zich goed analyseren aan de hand van algemeen aanvaarde marktgegevens en kunnen daardoor bewust worden genomen. Operationele risico's zijn niet altijd eenvoudig identificeerbaar en raken de gehele onderneming (Simon, 2004).

In dit artikel wordt gezocht naar een antwoord op de vraag op welke wijze operationeel risicomanagement in een onderneming, in het bijzonder in het verzekeringsbedrijf, kan worden geïmplementeerd, zodanig dat toegevoegde waarde wordt gerealiseerd, dat wil zeggen dat meer wordt bereikt dan alleen compliance.

Dat operationeel risicomanagement geen managementhype is, komt mede omdat er een stevige basis voor is/wordt gelegd in wet- en regelgeving. In Basel II en Solvency II wordt geëist dat financiële instellingen ook kapitaal aanhouden voor operationele risico's. Corporate governance codes, zoals Tabaksblat in Nederland en Sarbanes-Oxley in de Verenigde Staten, vragen om een interne beheersingsverklaring. De Nederlandsche Bank kent een risicogebaseerd toezicht en beoordeelt daarvoor ook de risicobeheersing van de onder toezicht staande instellingen. Rating agencies, zoals Standard \& Poor's en Moody's nemen het risicomanagement van een onderneming mee in hun beoordeling van de kredietwaardigheid. Men kan vaststellen dat operationeel risicomanagement een noodzakelijke voorwaarde is geworden om in de financiële sector actief en succesvol te kunnen zijn.

Risico wordt vaak in negatieve termen besproken: als bedreiging voor het realiseren van doelstellingen of 
als kans op verlies (men noemt dit wel de downside van risico). De nadruk ligt op de negatieve implicaties van slecht operationeel risicomanagement en de verliezen die daar het gevolg van zijn. De eerste doelstelling van operationeel risicomanagement is inderdaad de continuiteit van de onderneming te bevorderen door de risico's die een onderneming loopt tot een bewust aanvaard niveau te beheersen. Daarnaast is er nadrukkelijk ook een positieve kant (dit is de upside) van operationeel risicomanagement. Een betere beheersing van risico's levert concurrentievoordeel op, zeker als het samengaat met efficiency- en kwaliteitsverbetering. En een goede reputatie op het gebied van interne controle en integere bedrijfsvoering draagt bij an de aandeelhouderswaarde, al dan niet via de rating van de kredietwaardigheid. Voor ondernemingen die dat oppakken, is operationeel risicomanagement geen kwestie van moeten, maar een kwestie van willen.

Implementatie van operationeel risicomanagement is niet eenvoudig. Gegevens met betrekking tot operationeel risico zijn doorgaans beperkt beschikbaar en moeilijk te kwantificeren. Door de grote diversiteit aan gebeurtenissen en oorzaken van operationeel risico is het moeilijk daarvoor meetbare doelstellingen vast te stellen en te monitoren. Het verband tussen oorzaak en gevolg is vaak complex en de beheersing geschiedt deels op subjectieve gronden. Veel ondernemingen accepteren operationeel risico als een onvermijdelijke kostenpost die erbij hoort, een 'cost of doing business'.

De ondernemingscultuur is van grote invloed op het operationeel risicomanagement. In de bestudering en implementatie van operationeel risicomanagement ligt de nadruk in de regel op het meten van operationele risico's en op de verschillende maatregelen om deze risico's te mitigeren. Toch is het vaak de cultuur van de onderneming die bepaalt of een programma voor operationeel risicomanagement succesvol is of niet. Een cultuur waarin integriteit en bewustzijn van operationeel risico hoog in het vaandel staan, benadrukt de persoonlijke verantwoordelijkheid van alle medewerkers en bestrijdt een schuldcultuur waarin mensen risico's en verliezen verborgen houden uit angst voor represailles. Omdat implementatie van operationeel risicomanagement een cultuurverandering vergt, dient veel aandacht uit te gaan naar de beleving en perceptie van risico en risicobeheersing in een onderneming.

Operationeel risicomanagement is het effectiefst als het onderdeel is van de professionele moraal die vanzelfsprekend is. Om daartoe te komen, moeten een organisatie en de mensen die de organisatie vormen een ontwikkeling doormaken, die in het algemeen vaak verloopt van moeten (extrinsieke motivatie: nieuwe wetgeving, incidenten), via kunnen (formalisering van beleid: procedures, charters, interne regelgeving) naar willen (verinnerlijkte moraliteit).

De opbouw van dit artikel is als volgt. Een nadere begripsbepaling wordt kort gegeven in paragraaf 2 . In paragraaf 3 wordt de in het onderzoek toegepaste methodologie uiteengezet en paragraaf 4 bespreekt de belangrijkste onderzoeksresultaten. Paragraaf 5 sluit af met enkele conclusies.

\section{Begripsbepaling}

De laatste jaren tekent zich consensus af over de volgende definitie van operationeel risico: het risico van verlies als gevolg van inadequate of falende interne processen, mensen en systemen of als gevolg van externe gebeurtenissen. Sinds 2001 hanteert ook Basel (2001) deze definitie, die gebaseerd is op vier onderliggende oorzaken van operationeel risico (processen, mensen, systemen en externe gebeurtenissen). Dit biedt directe aanknopingspunten voor het maken van een risicoanalyse en de beheersing van operationeel risico. Onderscheid moet worden gemaakt tussen oorzaken, verliesgebeurtenissen en de winsten en verliezen die daar het gevolg van zijn. Operationeel risico kan op elk van deze drie aspecten worden geanalyseerd.

Minder overeenstemming is er als de definitie in concrete voorbeelden wordt uitgewerkt. In de regel wordt het strategisch risico, dat wil zeggen de vraag of de strategische beslissingen van een onderneming juist zijn en bijzondere risico's met zich meebrengen, niet tot het operationeel risico gerekend. Als de uitvoering van de strategie faalt, denk bijvoorbeeld aan te trage productontwikkeling, ondeugdelijke verkooppraktijken en falende kostenbesparingen, kan wel van een operationeel risico worden gesproken. Het Basel Committee (2005) rekent reputatierisico niet tot het operationeel risico, vanwege het praktische bezwaar dat deze risico's niet goed meetbaar zijn. Uitsluiting van het reputatierisico is om praktische redenen begrijpelijk, maar dat neemt niet weg dat het een significant risico is dat niet buiten beschouwing kan worden gelaten in het totale risicomanagement van een onderneming. Simons (2000) vindt reputatierisico, dat hij franchise risk noemt, juist het grootste risico, omdat het tot een snelle ondergang van de onderneming kan leiden als klanten, medewerkers en aandeelhouders het vertrouwen in de onderneming verliezen. 
Een te breed perspectief biedt geen aanknopingspunten voor risicomanagement. Een nadere rubricering van het operationeel risico is wenselijk om de algemene definitie meer inhoud te geven en af te bakenen. Ondernemingen die een te beperkte classificatie kiezen waarin een aantal soorten operationeel risico wordt uitgesloten omdat deze niet goed meetbaar zijn, accepteren daarmee het risico dat die risico's niet worden geanalyseerd en gemanaged. We moeten accepteren dat het begrip operationeel risico nooit volledig te beschrijven is, hetgeen tegelijkertijd een belemmering is voor risicomanagement. Hoe gedetailleerd de gekozen classificatie ook is, er zullen altijd meer en andere gebeurtenissen zijn die tot operationele verliezen kunnen leiden.

Een gestandaardiseerde methode is niet voorhanden, noch voor de wijze waarop een onderneming invulling zou moeten geven aan operationeel risicomanagement, noch voor de wijze waarop dit goed wordt geïmplementeerd. De bestaande publicaties op dit gebied zijn veelal korte artikelen of bloemlezingen, waarin verschillende auteurs deelaspecten nader uitwerken, zoals kwantificering en verzekering, of eigen raamwerken presenteren waarmee bijvoorbeeld aan de eisen van Basel II en corporate governance codes kan worden voldaan (Alexander, 2003; Risk Books, 2003; Chorafas, 2004; Emanuels en De Munnik, 2006). Anderen laten vooral best practices zien (Hoffman, 2002). Het raamwerk voor interne controle van COSO uit 1992, dat ook door Tabaksblat (Commissie corporate governance, 2003) als voorbeeld wordt genoemd, en vooral de uitbreiding daarvan tot een raamwerk voor enterprise risk management, lijken thans het meest gebruikt te worden. COSO hanteert een ruimer risicobegrip dan Basel en is toepasbaar voor de beheersing van diverse soorten ondernemingsrisico. COSO (2004, p. 16) definieert risicomanagement als volgt: "Enterprise risk management is a process, effected by an entity's board of directors, management and other personnel, applied in strategy setting and across the enterprise, designed to identify potential events that may affect the entity, and manage risks to be within its risk appetite, to provide reasonable assurance regarding the achievement of entity objectives."

Een aantal fundamentele concepten is in deze definitie verankerd. In de eerste plaats is risicomanagement een proces en daarmee middel in plaats van doel. De definitie maakt ook duidelijk dat mensen op alle niveaus in de organisatie het risicomanagement inhoud geven. Tegelijkertijd worden mensen ook door het risicomanagement beïnvloed. Het bepaalt mede hun verantwoordelijkheden, bevoegdheden, verplichtingen en de manier waarop zij hun werk doen. Risk appetite is de mate van risico die een onderneming bereid is te nemen, vaak in samenhang met de doelstellingen op het gebied van groei en rendement. Risicoafwegingen spelen een rol bij het bepalen van de strategie, het afwegen van alternatieven en het alloceren van middelen. Goed risicomanagement geeft de ondernemingsleiding redelijke zekerheid ten aanzien van strategie (zijn doelen in overeenstemming met de missie van de onderneming), operaties (effectief en efficiënt gebruik van middelen), de betrouwbaarheid van de verslaglegging en het voldoen aan wet- en regelgeving (compliance).

\section{Methodologie}

De afgelopen decennia is de benadering van organisatieverandering ingrijpend gewijzigd. Waar verandering eerst werd gezien als een bevel tot een nieuwe manier van werken van de hoogste baas, is nu vaker sprake van een proces waarin alle medewerkers worden betrokken. Het belang van empowerment, de organisatiecultuur en interne communicatie bij verandering wordt breed erkend. Een onderzoeksmethode die hierbij aansluit en hier wordt toegepast, is actieonderzoek (Reason en Bradbury, 2001). Dit is een participatieve en op samenwerking gerichte onderzoeksmethode, waarin theorie, onderzoek en praktijk worden geïntegreerd. In een cyclisch proces van handelen en reflecteren wordt kennis gegenereerd, theorie ontwikkeld en een verandering in de organisatie gerealiseerd. Het doel is zowel kennis te vergaren over de praktijk als de praktijk mee te sturen vanuit het onderzoek. Daarmee is actieonderzoek een middel voor organisatieverandering. Kenmerkend voor actieonderzoek is een cyclisch (in plaats van lineair) proces van actie en reflectie, van grof naar fijn. Handelen en reflecteren op dat handelen leiden tot leren en daarmee tot kennisgeneratie en theorieontwikkeling. De rol van de onderzoeker kan in actieonderzoek niet afstandelijk zijn. Het is niet alleen observeren, registreren en analyseren. Hij werkt lerend mee in de richting van het gestelde doel. Hij is dan ook noch onpartijdig noch onverschillig. Dit is afwijkend van traditionelere onderzoeksmethoden, waarin de onderzoeker geacht wordt objectief en onafhankelijk te analyseren en de rollen van onderzoeker en onderzochte strikt te scheiden. Actieonderzoek daarentegen onderkent dat iedere inmenging in het kader van onderzoek op zichzelf ook een interventie in het proces is en dat de onderzoeker daarmee het proces beïnvloedt. Bovendien kan de inbreng van de onder- 
zochten in het onderzoeksontwerp en de uitvoering daarvan het onderzoek ten goede komen.

Managementtechnieken voor het realiseren van organisatieverandering die uitgaan van de macht van de top van het bedrijf, resulteren in een openlijke navolging van hetgeen is opgedragen, met andere woorden compliance op de korte termijn. Er vindt echter geen verinnerlijking plaats. Daarvoor zijn leren, communicatie, betrokkenheid en werkelijke invloed van medewerkers bij organisatieverandering van belang. Als invloed in plaats van macht wordt uitgeoefend, creëert dat weinig openlijke conformiteit, maar wordt gevolg gegeven aan de doelen van de gewenste verandering alsof mensen die zelf bedacht en tot stand gebracht hebben. De omschakeling die dan plaatsvindt, heeft een veel langere termijn karakter. Dit inzicht is van belang voor een implementatie van operationeel risicomanagement die bijdraagt aan de ontwikkeling van de organisatie en aan het behalen van de ondernemingsdoelstellingen en niet beperkt blijft tot het voldoen aan de aangescherpte eisen van regelgevers en toezichthouders.

Actieonderzoek laat ruimte voor veel verschillende methoden, zoals literatuuronderzoek, interviews, brainstormsessies, observaties, consultaties, trainingen, groepsdiscussies, enquêtes, rollenspellen en vele andere. De keuze van de methode is maatwerk en kan in ieder actieonderzoek anders zijn. In het reflectiedeel van het actieonderzoek is gekozen voor de Q-methodologie, omdat die systematische studie van subjectiviteit mogelijk maakt. Het resultaat is een beschrijving van de dominante patronen in de opvattingen van betrokkenen over operationeel risicomanagement. Deze methode is ontwikkeld door Stephenson (1953) en onder andere uitgewerkt en toegepast door Brown (1996). Het is een kwalitatieve onderzoeksmethode, die gebruikmaakt van kwantitatieve, statistische technieken (factoranalyse). Een essentieel kenmerk is dat de Q-methodologie de uitspraken van de respondenten generaliseert en niet de respondenten. Geconcludeerd wordt niet dat een bepaald percentage van de respondenten iets vindt. Gezocht wordt naar de kenmerken van patronen in opvattingen (visies) en naar de mate waarin die overeenkomsten en verschillen vertonen. Daarvoor is, in tegenstelling tot veel kwantitatief onderzoek, geen groot aantal respondenten nodig.

Een Q-sort onderzoek begint met het verzamelen en selecteren van uitspraken over het onderwerp. Het geheel van uitspraken dat in het debat over een bepaald onderwerp aan de orde is, wordt het concourse genoemd. Het gaat daarbij om subjectieve stellingen of meningen, niet om objectieve waarheden.
Vervolgens wordt uit het ruwe materiaal een selectie gemaakt, de zogenaamde Q-sample. Dit zijn de uitspraken die aan de respondenten worden voorgelegd. De selectie moet zodanig worden gemaakt dat een representatieve miniatuur ontstaat van het grote geheel. Daartoe worden de stellingen gecategoriseerd en wordt binnen de categorie vastgesteld dat de stellingen het hele spectrum aan meningen afdekken en dat een aantal stellingen onderling onverenigbaar is. De Q-methodologie stelt geen eisen aan het aantal categorieën, het aantal stellingen per categorie of een evenredige verdeling van het aantal stellingen per categorie. Daar komt bij dat de interpretatie van de categorieën en stellingen van de onderzoeker kan afwijken van die van de respondenten. De reflectie van de respondent is belangrijker dan de categorisering die door de onderzoeker is bedacht. Respondenten wordt gevraagd de stellingen te ordenen van "helemaal mee oneens" ( -3$)$ tot "helemaal mee eens" $(+3)$ in een quasi-normaalverdeling. Er is sprake van een gedwongen ordening: het aantal stellingen per kolom staat vast en de respondent moet van evenveel stellingen aangeven dat hij het hier mee eens is als oneens. In de analyse is de plaats van de ene stelling ten opzichte van de andere belangrijker dan de individuele score op een stelling. Het resultaat van deze ordening heet een Q-sort.

De Q-sorts van alle respondenten worden statistisch geanalyseerd door middel van factoranalyse (Smolck, 2002). Hieruit komen factoren naar voren, dat wil zeggen stelsels van met elkaar samenhangende uitspraken. Iedere factor vertegenwoordigt een bepaalde visie op het onderwerp. Het aantal factoren dat uit de analyse naar voren komt, is afhankelijk van de Q-sorts en de mate van verscheidenheid daarin.

\section{Onderzoeksopzet en resultaten}

Het onderzoek heeft plaatsgevonden bij de Nederlandse verzekeringsmaatschappij AEGON in het bedrijfsonderdeel voor schadeverzekeringen. Het begin van het onderzoek was niet het begin van het denken over operationeel onderzoek in de organisatie. Er is sprake van interventie in een bestaande organisatie met een lange historie, waarin operationeel risicomanagement (impliciet) al op een bepaalde manier inhoud heeft gekregen. Er wordt dus niet iets geheel nieuws geïntroduceerd, maar wel wordt beoogd een impuls te geven aan operationeel risicomanagement en een nieuwe inhoud die beter aansluit bij de eisen van deze tijd. Op basis van eigen waarneming worden vier fasen onderscheiden in de ontwikkeling van operationeel risicomanagement, 
die in figuur 1 schematisch zijn weergegeven.

De "cirkels" van actie en reflectie in het actieonderzoek "helpen" de organisatie door deze fasen te migreren. In de praktijk zijn de verschillende cirkels in het onderzoek niet geheel van elkaar te scheiden en begint de tweede cirkel al voordat de eerste is afgerond. Dit wordt mede veroorzaakt door onvermijdelijke tempoverschillen tussen individuen en organisatieonderdelen.

De eerste cirkel in het actieonderzoek beslaat de ontwikkeling van fase 1 naar het begin van fase 3 . De bewustwording van de noodzaak van operationeel risicomanagement neemt sterk toe en de eerste structurele maatregelen worden genomen om operationeel risicomanagement in de organisatie te verankeren. De nadruk ligt op het voldoen aan wet- en regelgeving, waaronder Sarbanes-Oxley die eisen stelt aan de integriteit van de financiële rapportage. Bewustwording wordt geholpen door enkele gevallen van negatieve publiciteit. In oktober 2004 bijvoorbeeld beschuldigde de openbaar aanklager in New York, Eliot Spitzer, een verzekeringsmakelaar en verschillende verzekeraars in de Verenigde Staten van misleiding en manipulatie van klanten. In Nederland kan de negatieve publiciteit rondom aandelenleaseproducten en beleggingshypotheken als voorbeeld worden genoemd.

Acties die in deze periode door het onderzochte bedrijf zijn genomen, zijn onder andere de inrichting van een afdeling Risk Management. Ook zijn trainingen en presentaties verzorgd, waarin het doel van operationeel risicomanagement is toegelicht en is afgesproken dat de verantwoordelijkheid voor risicomanagement niet bij een stafafdeling ligt, maar in de lijnorganisatie. Risicobeheersing bestaat vooral uit correctie en repressie van de mogelijke negatieve gevolgen van de operationele risico's, zoals verrassingen in de resultaten en reputatieschade. Tegen het eind van deze eerste cirkel worden ook de voordelen van risicomanagement voor de bedrijfsvoering zichtbaarder. De toegenomen kennis van de processen en de risico's daarin worden gebruikt om fouten en verliezen te beperken, hetgeen leidt tot efficiencyverbeteringen en een betere kwaliteit.

In het reflectiedeel van de eerste cirkel in het actieonderzoek zijn met toepassing van de Q-methodologie 31 stellingen voorgelegd over het bewustzijn van de ernst en omvang van operationele risico's, het nut van operationeel risicomanagement en de verantwoordelijkheid voor risicomanagement en de te nemen maatregelen. Hieruit kwam naar voren dat binnen de onderneming drie visies met betrekking tot operationeel risicomanagement bestaan:

- Visie 1: focus op interne processen voor verbetering van efficiency en kwaliteit

Aanhangers van deze visie zijn vooral intern gericht en beschouwen risicomanagement als een middel om de efficiency en de kwaliteit van de bedrijfsvoering te verbeteren. Zij streven een bedrijfsvoering na die als een goed geoliede machine is met strak geregisseerde processen die weinig ruimte laten voor eigen inbreng van medewerkers.

Figuur 1 Fasen in de ontwikkeling van operationeel risicomanagement

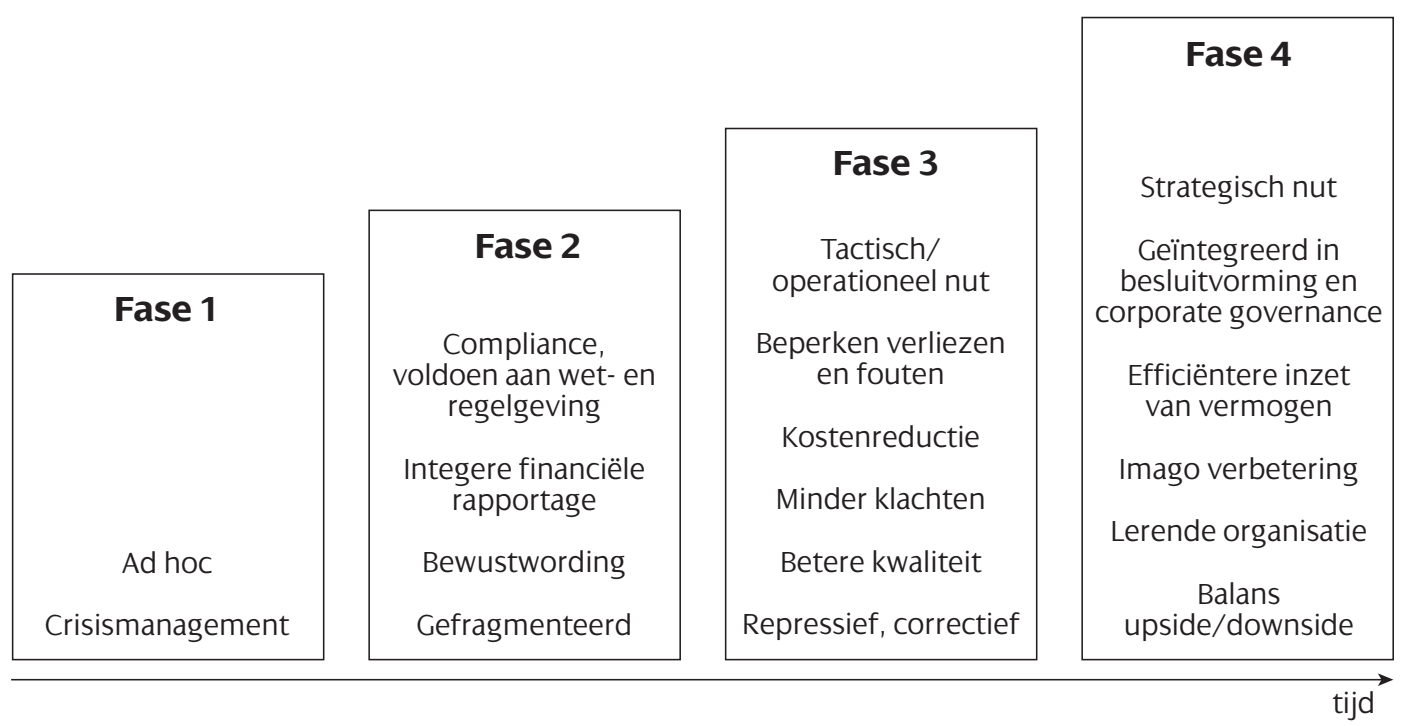


- Visie 2: focus op gedrag en eigen verantwoordelijkheid van mensen

Deze groep verwacht van iedereen een manier van werken die in het belang van het bedrijf is en in overeenstemming met de geest van de richtlijnen. Participatie van medewerkers bij besluitvorming wordt belangrijk gevonden, maar dit gaat niet samen met een groot vertrouwen in mensen. Meer dan de aanhangers van de andere visies wordt controle noodzakelijk geacht.

- Visie 3: focus op extern imago bij aandeelhouders en klanten

Door deze groep wordt een aanzienlijk publiciteitsrisico onderkend. Operationele blunders schaden het vertrouwen en belemmeren daarmee de groei en winstgevendheid van het bedrijf. Door risicomanagement expliciet zichtbaar te maken, kan de aandelenkoers positief worden beïnvloed en concurrentievoordeel worden behaald. Deze groep hecht aan beperking van de volatiliteit en ziet risicomanagement als een middel daarvoor.

In alle visies wordt het belang van risicomanagement onderschreven, maar de oorzaak van dat belang en de wijze waarop daaraan invulling moet worden gegeven verschillen. Toch sluiten de verschillende visies elkaar niet geheel uit en bleek de correlatie tussen de visies redelijk hoog. Consensus is noch haalbaar noch nodig. Er blijken voldoende aanknopingspunten om gezamenlijk aan risicobeheersing te werken. Het gaat dan ook niet om een keuze voor één van de drie visies, maar om een pakket maatregelen waarin een balans tussen de verschillende belangen wordt bereikt. Hierdoor wordt voorkomen dat een deel van de mensen, wier problemen niet worden geadresseerd, als het ware afhaakt.

In de tweede cirkel van het actieonderzoek werd geprobeerd een brug te slaan van noodzaak naar nut van operationeel risicomanagement en zo ver mogelijk in fase 4 te komen. Met andere woorden, het doel is dat de wijze waarop operationeel risicomanagement wordt ervaren, verschuift van een noodzakelijk kwaad tot een positief instrument voor de verdere professionalisering van de bedrijfsvoering. Managers die operationeel risicomanagement ook strategisch gaan beschouwen en risicomanagement in de besluitvorming integreren, zoeken niet alleen naar risicoreductie, maar veel meer naar risico-optimalisatie.

Bij deze fase past een pro-actief risicomanagement. In plaats van bestaande processen achteraf te analyseren en beheersbaar te maken, wordt bij het ontwerpen van processen en projecten reeds rekening gehouden met de daaraan verbonden risico's en beheersingsmaatregelen. Concreet is hieraan invulling gegeven door risk \& control self-assessment workshops, waarin met directbetrokkenen risico's en beheersingsmaatregelen worden geïdentificeerd en beoordeeld. Workshops vergroten de betrokkenheid van de deelnemers en hun verantwoordelijkheidsgevoel voor risico's en risicobeheersing. Dit bevordert de cultuur ten aanzien van operationeel risicomanagement. Ook is in deze fase operationeel risicomanagement verder geïnstitutionaliseerd door de uitrol van nieuwe software, waarin processen, risico's en beheersingsmaatregelen vastliggen en worden bewaakt, en door instelling van een Risk Committee, dat minimaal eens per kwartaal bijeen komt.

In het kader van de reflectie in de tweede cirkel van het actieonderzoek is nogmaals de houding ten aanzien van risicomanagement gepeild. In de tweede $Q$-sort werden grotendeels andere stellingen voorgelegd dan in de eerste Q-sort. Het doel is namelijk niet om een hertest uit te voeren naar de betrouwbaarheid van een eerdere meting. Het is inherent aan actieonderzoek dat de uitkomst verandert, mede vanuit het besef dat een meting een interventie is. Uit de eerste Q-sort werd duidelijk dat het bewustzijn van nut en noodzaak van risicomanagement in ruime mate aanwezig is. In de tweede Q-sort zijn stellingen voorgelegd over de rol van de afdeling Risk Management, de visie op controle en de impact van risico- en procesbeheersing op ondernemerschap en innovatie. Ook komen de stellingen terug uit de eerste Q-sort die kenmerkend zijn voor de drie gevonden visies. Bij analyse van de resultaten bleek de relatie tussen risicomanagement en innovatie door de respondenten niet als zeer onderscheidend opgepakt te zijn. Dit zijn de (wederom drie) gevonden visies:

- Visie 1: voorkeur voor bottom-up en decentrale implementatie van risicomanagement

Degenen die deze visie aanhangen, nemen zelf de verantwoordelijkheid voor risicomanagement op zich en zien voor een afdeling Risk Management een rol op de achtergrond, vooral ter ondersteuning en advisering. Verantwoordelijkheid moet laag in de organisatie worden gelegd en controle is een noodzakelijk kwaad.

- Visie 2: voorkeur voor top-down en centraal gecoördineerde implementatie van risicomanagement

Deze groep geeft de voorkeur aan centrale sturing. Het is goed als door een afdeling Risk Management duidelijke kaders worden gegeven en eisen worden gesteld. Controle is onmisbaar.

- Visie 3: focus op extern imago bij aandeelhouders en klanten

Deze groep vertoont sterke overeenkomsten met visie 3 
in de eerste Q-sort. Deze groep heeft geen onderscheidende mening over controle en over centrale of decentrale implementatie van risicomanagement.

Bij wijze van hypothese is aan de respondenten van de tweede Q-sort tenslotte figuur 2 voorgelegd, die de relatie weergeeft tussen operationeel risicomanagement en toegevoegde waarde. Toegevoegde waarde is positief als de baten van operationele risicobeheersing (bijvoorbeeld betere efficiency, kwaliteit, minder fouten en minder gemiste kansen) hoger zijn dan de kosten ervan. Bij punt A is compliance bereikt. Dit is een minimumeis, die geen toegevoegde waarde levert, maar een noodzakelijke voorwaarde is voor het bestaan van de onderneming. Voorbij punt B slaat risicobeheersing te ver door. De marginale kosten van risicobeheersing worden hoger dan de marginale opbrengsten. Voorbij punt $\mathrm{C}$ is de toegevoegde waarde van risicomanagement negatief. Alle risico's zijn geëlimineerd, alle processen kloppen, maar de kosten van risicobeheersing zijn enorm en het ondernemerschap is verloren gegaan.

In figuur 2 is aangegeven hoeveel respondenten de onderneming op welk deel van de curve positioneren. Breed wordt erkend dat risicomanagement toegevoegde waarde biedt en dat er nog ruimte is voor verdere beheersing. Het punt waarop er meer risicobeheersing plaatsvindt dan goed is voor de onderneming, is nog niet bereikt. Slechts op enkele deelaspecten wordt aangegeven dat de beheersing meer eisen stelt dan noodzakelijk en de snelheid van handelen beperkt.

\section{Conclusies}

Operationeel risicomanagement is een essentieel onderdeel van goed ondernemerschap. Hoe meer het operationeel risicomanagementbeleid en het ondernemingsbeleid op elkaar worden afgestemd of nog beter, hoe meer het operationeel risicomanagementbeleid in het ondernemingsbeleid is geïntegreerd, hoe effectiever het is. De manier waarop beslissingen tot stand komen, afspraken met klanten en leveranciers worden gemaakt en medewerkers worden opgeleid, moeten in overeenstemming zijn met het beleid ten aanzien van operationeel risico.

Operationeel risicomanagement is hier benaderd vanuit het perspectief van het verzekeringsbedrijf met de vraag op welke wijze operationeel risicomanagement toegevoegde waarde kan hebben voor de onderneming. Dat wil zeggen dat niet alleen wordt voldaan aan de eisen van regelgevers en toezichthouders, maar dat ook de kwaliteit van de bedrijfsvoering wordt verbeterd en de concurrentiepositie wordt versterkt, bijvoorbeeld door een efficiëntere aanwending van het vermogen. Voor de implementatie van operationeel risicomanagement is actieonderzoek ingezet als middel voor organisatieontwikkeling. Dat lukt niet door de introductie van overlegstructuren, rapportages en softwareapplicaties alleen. Er is daarom ook veel aandacht besteed aan de beleving van risico en risicobeheersing in de onderneming.

In dit onderzoek werden vier fasen zichtbaar bij de ontwikkeling van operationeel risicomanagement. Daarmee is niet gezegd dat alle ondernemingen hetzelfde proces moeten of zullen doormaken. Het is

Figuur 2 Relatie tussen mate van operationeel risicomanagement en toegevoegde waarde

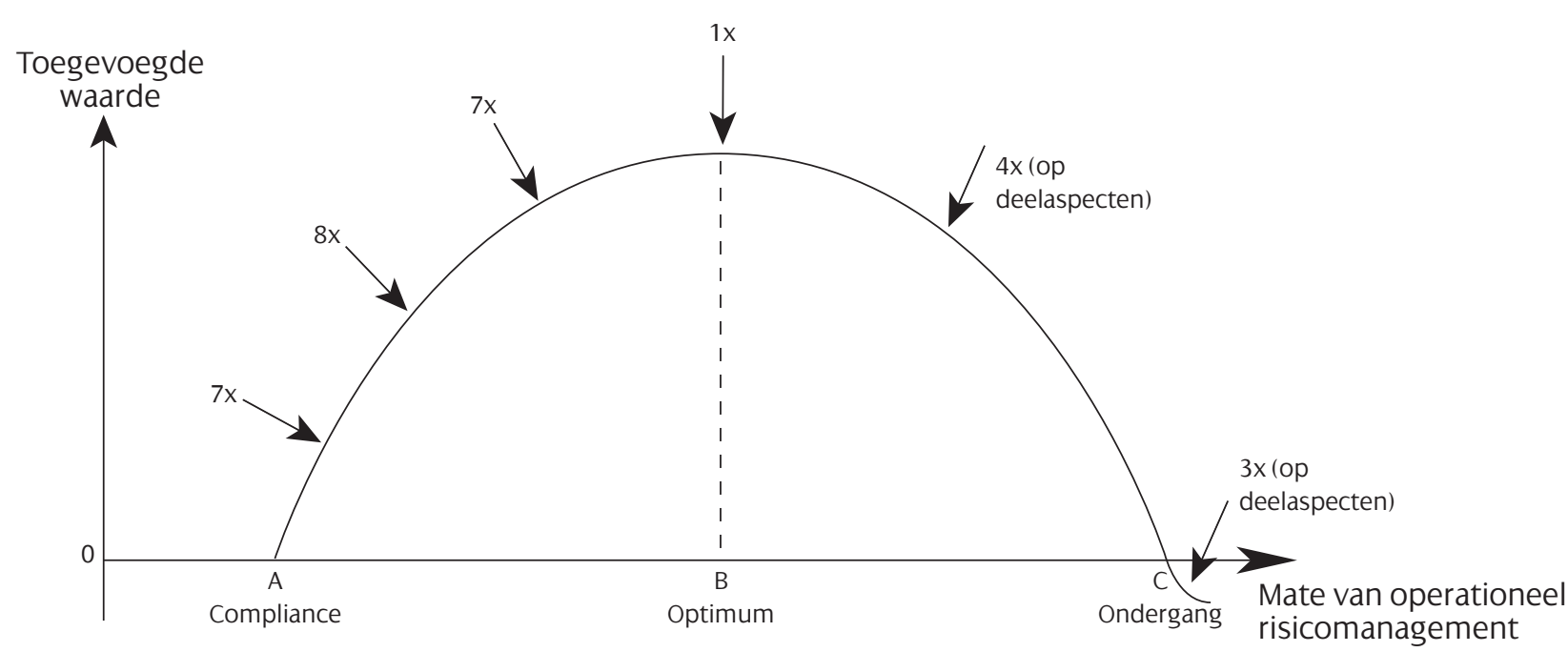


goed mogelijk dat er verschillende startpunten zijn en verschillende wegen die naar hetzelfde doel leiden. Voor een duurzame verankering van risicomanagement in de organisatie, is de reis die de onderneming aflegt vrijwel net zo belangrijk als de eindbestemming. Risicomanagement behoort tot de grootste uitdagingen voor ondernemingen. De risico's die samenhangen met bedreigingen moeten worden beheerst, zodanig dat de kans dat het risico zich voordoet wordt verkleind en als dat toch gebeurt, dat de impact daarvan kleiner is. De kans dat een 'business opportunity' zich voordoet en het mogelijke voordeel daaruit, moeten worden gemaximaliseerd. Het gaat erom de juiste balans tussen risico en opbrengst te vinden. De taak van de risicomanager is dan ook niet risicobeperking, maar het bevorderen dat risico's bewust worden genomen. Eigenlijk moeten we terug naar de oorspronkelijke betekenis van het woord risico, dat afkomstig is van het vroeg-Italiaanse 'risicare' en dat durven betekent (Bernstein, 1996). Risico is dan een keuze en niet iets dat je overkomt.

Een te sterke nadruk op het risico dat (nieuwe) ondernemingsactiviteiten met zich mee brengt en op het beperken van risico kan verlammend op een organisatie werken. Het zal dan moeilijk zijn voldoende aandacht voor operationeel risicomanagement ook op langere termijn vast te houden. Benadrukt moet worden dat de beheersing van operationele risico's meer zekerheid geeft ten aanzien van het realiseren van de ondernemingsdoelstellingen en kansen biedt met betrekking tot een beter imago, meer tevreden klanten, een groter behoud van klanten, meer verkoop, marktaandeel en winstgevendheid. Het echte voordeel is te behalen in het benutten van deze kansen. Daarmee is operationeel risicomanagement een breder onderwerp dan het voldoen aan regelgeving en aan de wensen van toezichthouders.

Operationeel risicomanagement kent ook beperkingen. Om te beginnen is operationeel risicomanagement geen garantie dat de onderneming niet failliet gaat. Zonder risicobeheersing zal faillissement zich waarschijnlijk sneller aandienen, maar ook met effectieve risicobeheersing is niet gezegd dat alle doelstellingen altijd worden gerealiseerd. De toekomst is onzeker, niet alle gebeurtenissen zijn te voorzien en niet alles gebeurt zoals tevoren bedacht.

Totale operationele risicobeheersing kost meer dan het oplevert. De uitdaging is een zodanige balans te vinden dat de toegevoegde waarde van risicomanagement maximaal is en dat betekent niet maximale risicobeperking. Volledige beheersing is een mythe en daarom is dit zeker geen pleidooi voor een 'auditexplosie'. Als alle risico's worden geëlimineerd, treedt fatale verlamming op. Als alle processen kloppen en alle controlemaatregelen worden uitgevoerd, maar er geen ondernemerschap meer is, dat wil zeggen geen risico meer wordt genomen, gaat de onderneming in schoonheid ten onder'. Meer is niet altijd beter.

\section{Literatuur}

Alexander, C. (2003), Operational risk: regulation, analysis and management, Financial Times Prentice Hall, London.

Basel Committee on Banking Supervision (2001), Working Paper on the Regulatory Treatment of Operational Risk, Bank for International Settlements, Basel.

Basel Committee on Banking Supervision (2005), International Convergence of Capital Measurements and Capital Standards: a revised Framework, Bank for International Settlements, Basel (first published June 2004, updated November 2005).

Bernstein, P.L. (1996), Against the gods. The remarkable story of risk, Wiley, New York.

Brown, S.R. (1996), Q Methodology and Qualitative Research, Qualitative Health Research, 1996 (November), vol. 6, no. 4, pp. 561-567.

Chorafas, D.N. (2004), Operational Risk Control Business Opportunity and Challenges for the Insurance Industry, in: The Geneva Papers on Risk and Insurance, Vol. 29, No. 1 (January 2004), The International Association for the Study of Insurance Economics, Blackwell Publishing, Oxford.

Commissie corporate governance (2003), De Nederlandse corporate governance code. Beginselen van deugdelijk ondernemingsbestuur en beste practice bepalingen, www.corpgov.nl.

COSO, The Committee of Sponsoring Organizations of the Treadway Commission (2004), Enterprise Risk Management - Integrated Framework, www.coso.org.

Emanuels, J.A. en W.G. de Munnik (2006), Enterprise Risk Management; een risicobeheersingssysteem voor organisaties, Maandblad voor Accountancy en Bedrijfseconomie, jg. 80, nr. 6, pp. 294-299.

Hoffman, D.G. (2002), Managing operational risk: 20 firmwide best practice strategies, Wiley, New York.

Leenaars, J.J.A. (2003), Risicomanagement van banken, Maandblad voor Accountancy en Bedrijfseconomie, jg. 77, nr. 7/8, pp. 340-347.

Reason, P. en H. Bradbury (ed.) (2001), Handbook of Action Research. Participative Inquiry and Practice, Sage, London.

Ridder, W.P. de (2006), Risicobeheersing met toegevoegde waarde. Een actieonderzoek naar de introductie van operationeel risicomanagement in een verzekeringsbedrijf, proefschrift, www.wpderidder.nl.

Risk Books (2003), Advances in Operational Risk. Firm-wide Issues for Financial Institutions, Risk Books, London.

Simon, B. (2004), Operational risk management, a view from the mill, in: Banking and Finance, vol. 15, no. 5 (oktober/november), pp. 95-99.

Simons, R. (2000), Performance Measurement and Control Systems for Implementing Strategy, Prentice-Hall, London.

Smolck, P. (2002), PQMethod Manual, distributed with the PQMethod package, PQMethod-2.11, November 2002, www.rz.unibw-muenchen. de/ p41bsmk/qmethod/pqmanual.htm.

Stephenson, W. (1953), The Study of Behavior. Q-Technique and its Methodology, University of Chicago Press, Chicago. 